\title{
Perubahan warna semen ionomer kaca setelah direndam dalam larutan teh hitam
}

\author{
*Wahyu Puri Wardhani, *Asti Meizarini, *Anita Yuliati, **Retna Apsari \\ *Departemen Material Kedokteran Gigi Fakultas Kedokteran Gigi \\ **Departemen Fisika Fakultas Sain dan Teknologi \\ Universitas Airlangga \\ Surabaya, Indonesia
}

\begin{abstract}
Microporosity in glass ionomer cement contributes on its colour stability. In oral cavity GIC interacts with saliva, foods, drinks, and the oral hygiene condition which could affect in colour stability. This study aimed to examine the colour change in GIC after immersion in black tea solution. Twenty eight disc specimens $(6 \mathrm{~mm}$ diameter and $1 \mathrm{~mm}$ thickness). The colour measurements were recorded after storage in closed tube for 24 hours. Specimens were randomly devided into 4 groups of 7 specimens. Control specimens were kept in saline solution. The other 3 groups were immersed in black tea solution for 5 minutes respectively for 5, 7, and 14 times, followed by colour change measurement. Data were submitted to one-way ANOVA and LSD. There was significant colour change in GIC after immersion in black tea. The conclusion is longer GIC immersed in black tea lower the intensity. The lowest intensity changing was the immersed for 5 minutes, 14 times daily.
\end{abstract}

Key words: glass ionomer cement, colour change, black tea

\begin{abstract}
ABSTRAK
Porositas mikro dalam semen ionomer kaca berperan terhadap stabilitas warna. Di dalam mulut, SIK berinteraksi dengan saliva, makanan, minuman dan kebersihan mulut yang dapat mempengaruhi stabilitas warna. Tujuan penelitian ini untuk menguji perubahan warna SIK setelah direndam dalam larutan teh hitam. Sebanyak 28 spesimen (diameter $6 \mathrm{~mm}$ dan tebal $1 \mathrm{~mm}$ ) diukur warnanya setelah disimpan dalam tabung tertutup selama 24 jam. Spesimen dibagi secara acak menjadi 4 kelompok, masing-masing 7 spesimen. Spesimen kontrol disimpan dalam saliva. Tiga kelompok lain direndam dalam larutan teh hitam selama 5 menit sebanyak 5x, 7x, dan 14x, kemudian perubahan warna dicatat/diukur. Data dianalisis dengan ANOVA satu arah dan LSD. Hasil penelitian menunjukkan ada perubahan warna yang bermakna dalam SIK setelah perendaman dalam larutan teh hitam. Disimpulkan bahwa semakin lama SIK diredam dalam larutan teh hitam, semakin rendah intensitas perubahan warna, perubahan intensitas yang paling rendah direndam selama 5 menit diulang 14 kali.
\end{abstract}

Kata kunci: semen ionomer kaca, perubahan warna, teh hitam

Koresponden: Wahyu Puri Wardhani. Departemen Material Kedokteran Gigi Fakultas Kedokteran Gigi Universitas Airlangga. Jl. Mayjen Prof Dr. Moestopo No. 47, Surabaya 60132, Surabaya, Indonesia. E-mail: aruslan @ hotmail.com.

\section{PENDAHULUAN}

Dalam beberapa dekade terakhir ini berbagai bahan untuk kepentingan estetik dengan berbagai sifat karakteristik dan warna telah beredar di pasaran. Salah satunya adalah SIK digunakan sejak awal tahun 1970, yang merupakan gabungan 
dari semen silikat dan semen polikarboksilat. Penggabungan ini bertujuan untuk mendapatkan sifat translusen dan kemampuan melekat secara kimia pada gigi, sehingga golongan semen ini memenuhi syarat sebagai bahan tumpatan. ${ }^{1}$ Semen ionomer kaca yang digunakan untuk menumpat gigi anterior mempunyai estetik yang baik, tetapi memiliki kekurangan, yaitu sifat rapuh. Sifat rapuh ini menunjukkan bahwa mikroporositas dari SIK cukup tinggi. ${ }^{2}$ Mikroporositas pada SIK akan mempengaruhi kemampuan bahan ini untuk menjaga kestabilan warna.

Perubahan warna bahan tumpatan sewarna gigi merupakan salah satu masalah estetika yang sering dialami oleh masyarakat terutama yang profesinya banyak berhubungan dengan masyarakat. Hal ini dapat menyebabkan gangguan psikologi, antara lain kurang percaya diri atau rasa malu. Peningkatan pengetahuan masyarakat tentang perawatan gigi yang mengalami perubahan warna semakin berkembang terutama keinginan untuk memperbaiki penampilan diri atau estetik. Syarat estetik suatu bahan restorasi gigi adalah tidak mengalami perubahan warna dalam jangka waktu yang lama, oleh karena itu diperlukan kestabilan warna.

Perubahan warna dari semen inomer kaca dapat disebabkan oleh faktor internal dan eksternal. Bila terjadi penetrasi dan resorbsi zat pewarna dari lingkungan dalam rongga mulut akan terbentuk lapisan superfisial pada SIK. Lapisan tersebut menyebabkan terjadinya perubahan warna di permukaan atau sub permukaan bahan restorasi tersebut. Hal ini merupakan faktor eksternal yang sangat mempengaruhi perubahan warna tersebut. ${ }^{3}$

Saat ini di tengah masyarakat banyak dijumpai berbagai jenis makanan ataupun minuman yang mengandung zat warna, alami ataupun buatan. Salah satu jenis minuman yang mengandung zat warna alami adalah teh. Teh merupakan jenis minuman berwarna yang umum dan banyak dikonsumsi masyarakat Indonesia. Ada beberapa macam teh, antara lain teh hitam, teh hijau, dan teh merah. Ketiga teh tersebut berasal dari daun tanaman Camelia sinensis yang mengandung katekin. Katekin bersifat larut dalam air, tidak berwarna, memberikan rasa pahit dan astringen atau kelat. Pengolahan menjadi teh hitam dilakukan melalui proses fermentasi penuh kemudian dikeringkan, sehingga katekin dapat teroksidasi membentuk warna dan cita rasa yang khas. Secara klasik warna teh hitam dapat dibagi ke dalam orange-coloured tehflavins (TFs), yang memberikan warna merah keemasan, dan brownish teharubigins (TRs), yang memberikan warna kecoklatan. Dalam teh hitam, TFs dapat dikelompokkan menjadi empat, yaitu tehflavin, tehflavin-3-gallat, tehflavin-3'-gallat dan tehflavin-3,3'-gallat, membentuk reaksi antara turunan kuinon dari sebuah katekin sederhana dan gallokatekin. TRs merupakan sebuah kelompok heterogen warna fenolik dengan massa molekul relatif pada rentang 700-40.000. Kandungan berbagai senyawa inilah yang membuat teh menjadi berwarna merah keemasan atau kecoklatan. ${ }^{4}$ Teh hitam inilah yang digunakan sebagai variabel eksternal yang mempengaruhi perubahan warna dari SIK dalam penelitian ini, dengan mempertimbangkan frekuensi kebiasaan minum secara umum selama 5 menit sebanyak 5 kali dalam sehari. ${ }^{5}$

Laboratorium Optika dan Aplikasi Laser Departemen Fisika Fakultas Sains dan Teknologi berkolaborasi dengan Departemen Material Kedokteran Gigi Fakultas Kedokteran Gigi Universitas Airlangga berupaya mendesain rancangan peralatan alternatif yang minim efek samping untuk menguji perubahan warna dengan metode optik berbasis pola intensitas difraksi dari 
hasil sensor charge coupled device (CCD) garis terkomputerisasi berbasis laser. Keunggulan alat ini mampu menampilkan pola distribusi intensitas secara keseluruhan dan waktu sebenarnya. ${ }^{6}$

Penulisan artikel ini bertujuan untuk memaparkan hasil penelitian yang dilakukan untuk mengetahui perubahan warna pada SIK setelah berinteraksi dengan seduhan teh hitam dengan frekuensi kebiasaan minum secara umum.

\section{BAHAN DAN METODE}

Semen ionomer kaca jenis II (Fuji GC) digunakan sebagai sampel dengan diameter $6 \mathrm{~mm}$, ketebalan $1 \mathrm{~mm}$ (disesuaikan dengan spesifikasi dari alat uji). Seduhan teh hitam dibuat dari teh hitam (®Sosro). Perubahan warna yang terjadi diuji menggunakan seperangkat alat deteksi perubahan warna (gambar 1).

Sebanyak 28 buah sampel dibagi menjadi 4 kelompok dengan selang waktu pengulangan 5 menit. Kelompok I (kontrol) direndam dalam 10 ml larutan saline selama 5 menit. Kelompok II direndam dalam larutan teh hitam selama 5 menit diulang 5 kali. Kelompok III direndam dalam larutan teh hitam selama 5 menit diulang 7 kali. Kelompok IV direndam dalam larutan teh hitam selama 5 menit diulang 14 kali.

Sampel dibuat dengan perbandingan 1 sendok peres bubuk dan 1 tetes cairan SIK sesuai dengan aturan pabrik, diletakkan pada kertas pengaduk. Bubuk dibagi menjadi 2 bagian yang sama, sebagian bubuk dan cairan diaduk selama 10 detik. Sisa bubuk di masukkan ke dalam adukan dan diaduk selama 15-20 detik sehingga total lama pengadukan 30 detik. Selanjutnya bagian bawah cetakan dari fiberglass diberi celluloid strip dan diletakkan di atas glasslab, SIK yang sudah diaduk dimasukkan ke dalam cetakan. Bagian atas cetakan diberi celluloid strip kemudian ditekan dengan glasslab, diberi beban $1 \mathrm{~kg}$, dibiarkan hingga mengeras selama 5 menit. Selanjutnya sampel dilepas dari cetakan, dimasukkan dalam wadah plastik kemudian ditutup rapat disimpan selama 24 jam.

Sebelum pengujian sampel terlebih dahulu dilakukan pengaturan alat. Pertama mengatur jarak antar sampel dan kamera CCD garis sebesar $57 \mathrm{~cm}$ kemudian jarak antara sampel dengan laser He-Ne sebesar $20 \mathrm{~cm}^{7}$ Kedua, menghubungkan kabel interface dari $\mathrm{CCD}$ ke kamera $\mathrm{CCD}$, dengan menghubungkan kabel pararel dari interface $\mathrm{CCD}$ ke komputer. Ketiga, menghubungkan kabel paralel catu daya komputer ke penyedia daya, dan menghubungkan kabel sumber daya ke sumber tegangan. Kemudian, tempatkan sumber cahaya laser He-Ne pada meja penelitian, dan dihubungkan ke sumber tegangan.

Persiapan pemilihan filter adalah menghidupkan komputer, sensor CCD dan laser He-Ne. Setelah itu meletakkan sampel seperti pada gambar 1. Filter yang terpilih dalam penelitian ini adalah filter bewarna putih yang mampu meneruskan laser He-Ne, agar terbentuk pola distribusi intensitas yang bisa dianalisis ditandai dengan munculnya grafik Gaussian pada layar komputer.

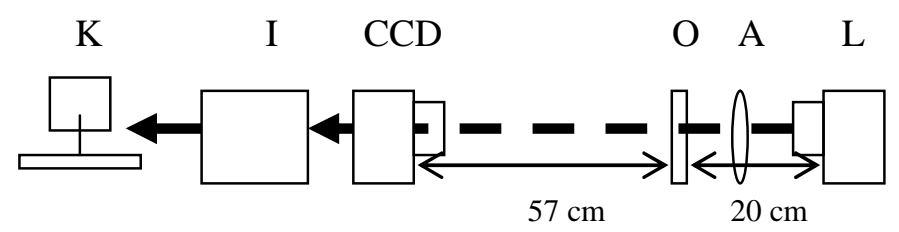

Gambar 1. Set-up alat pendeteksi perubahan intensitas warna. L: Laser He-Ne; A: Filter; O: Obyek/sampel; CCD: charge coupled device; $\mathrm{I}$ : Interface; K: seperangkat komputer. 
Tahap penelitian adalah disiapkan wadah untuk larutan saline dan seduhan teh hitam. Sampel direndam sesuai dengan kelompok perlakuan. Sampel yang selesai direndam, diambil dibiarkan sampai mengering, kemudian diletakkan pada kertas karton yang telah dilubangi untuk memudahkan pemasangan sampel agar tegak lurus dan untuk mengurangi gangguan yang terdeteksi oleh CCD. ${ }^{6}$ Selanjutnya, sumber sinar laser $\mathrm{He}-\mathrm{Ne}$ dilewatkan pada filter dan sampel sampai ditangkap oleh sensor CCD, pola distribusi intensitas diamati pada layar komputer dicatat nilai maksimal dengan sumbu kursor horisontal (Y1 dan Y2). Nilai maksimal inilah yang menunjukkan nilai intensitas dalam satuan lux.

\section{HASIL PENELITIAN}

Hasil perubahan warna SIK setelah direndam dalam larutan saline dan teh hitam berdasarkan pembagian kelompok perlakuan seperti yang tercantum pada tabel 1.

Berdasarkan tabel 1 dapat diketahui bahwa rerata perubahan intensitas warna SIK setelah direndam dalam larutan saline dan seduhan teh hitam. Semakin lama direndam, nilai intensitas perubahan warna semakin menurun. Nilai intensitas yang menurun menunjukkan warna sampel semakin gelap.

Nilai intensitas tertinggi pada sumbu Y pada gambar 1A menunjukkan angka 3783 lux (kelompok kontrol). Pada Gambar 1B, kelompok IV nilai intensitas tertinggi pada angka 2911 lux. Data yang diperoleh diuji normalitas dan homogenitasnya dengan Kolmogorov-Smirnov, menunjukkan terdistribusi normal dan homogen, selanjutnya diuji dengan Anova satu arah.

Tabel 1. Rerata dan simpang baku intensitas perubahan warna SIK pada setiap kelompok perlakuan (lux)

\begin{tabular}{ccccc}
\hline $\begin{array}{c}\text { No. } \\
\text { Sampel }\end{array}$ & $\begin{array}{c}\text { Larutan saline } \\
\text { (kontrol) }\end{array}$ & $\begin{array}{c}\text { Direndam dalam } \\
\text { teh hitam 5x }\end{array}$ & $\begin{array}{c}\text { Direndam dalam } \\
\text { teh hitam } 7 \mathrm{x}\end{array}$ & $\begin{array}{c}\text { Direndam dalam } \\
\text { teh hitam 14x }\end{array}$ \\
\hline 1 & 3643 & 3400 & 3043 & 2911 \\
2 & 3783 & 3400 & 3087 & 2722 \\
3 & 3736 & 3311 & 3087 & 2722 \\
4 & 3643 & 3400 & 3043 & 2830 \\
5 & 3736 & 3400 & 3043 & 2911 \\
6 & 3736 & 3244 & 3043 & 2911 \\
7 & 3736 & 3333 & 3087 & 2911 \\
\hline $\bar{X} \pm S B$ & $3722,86 \pm 55.46$ & $3352,57 \pm 67,87$ & $3061,86 \pm 23,52$ & $2845,43 \pm 89,36$ \\
\hline
\end{tabular}

Keterangan: $\bar{X}=$ Rerata; SB = Simpang Baku
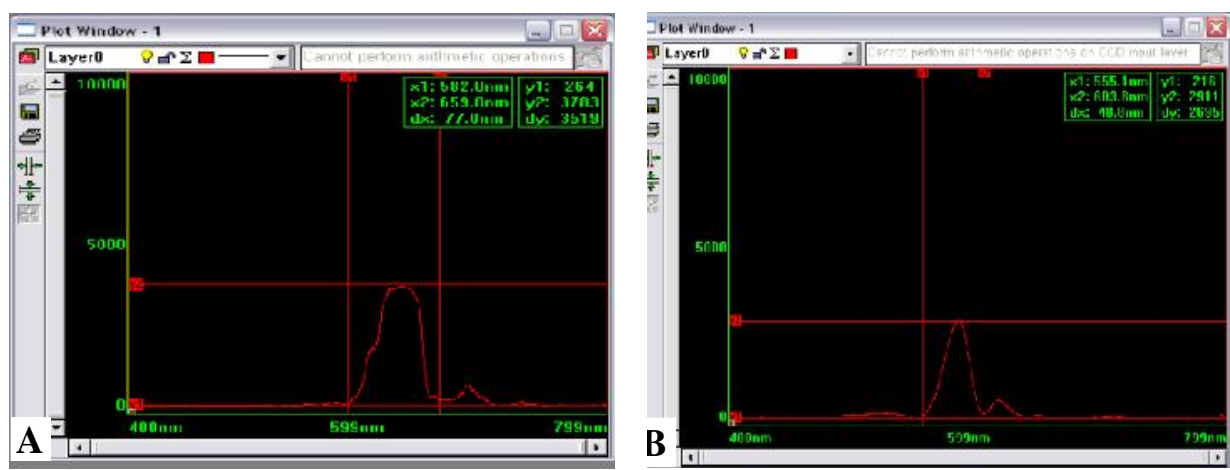

Gambar 1. Grafik Gaussian A. menunjukkan nilai intensitas perubahan warna pada kelompok kontrol. B. menunjukkan nilai intensitas perubahan warna pada kelompok IV. 
Tabel 2. Uji Anova satu arah intensitas perubahan warna SIK setelah direndam dalam larutan teh hitam.

\begin{tabular}{cccccr}
\hline Sumber Variasi & Jumlah kuadrat & Derajat kebebasan & Rata-rata kuadrat & F & Kemaknaan \\
\hline Antar kelompok & 3031810,96 & 3 & 1010603,66 & 244,08 & 0,000 \\
Dalam kelompok & 99371,14 & 24 & 4140,46 & & \\
\hline Total & 3131182,11 & 27 & & & \\
\hline
\end{tabular}

Tabel 3. Uji LSD perubahan intensitas warna SIK setelah direndam dalam teh hitam

\begin{tabular}{lcccc}
\hline & Kontrol & Direndam dalam teh & Direndam dalam teh & Direndam dalam teh \\
& & $5 \mathrm{x}$ & $7 \mathrm{x}$ & $14 \mathrm{x}$ \\
\hline Kontrol & - & & & \\
Direndam 5x & $*$ & - & & \\
Direndam 7x & $*$ & $*$ & $*$ & - \\
Direndam 14x & $*$ & $*$ & $*$ & \\
\hline
\end{tabular}

*: bermakna

Hasil uji statistik Anova satu arah diperoleh nilai signifikansi $\mathrm{p}=0,000 \quad(<0,05)$. Hal ini menunjukkan ada perbedaan bermakna antar kelompok perlakuan. Untuk mengetahui beda antar kelompok perlakuan dilanjutkan uji LSD, dapat dilihat pada tabel 3 .

Perubahan intensitas warna pada kelompok kontrol dibanding ke tiga kelompok perlakuan perendaman SIK dalam larutan teh hitam terdapat perbedaan yang bermakna, dengan nilai $\mathrm{p}=0,00$.

\section{PEMBAHASAN}

Deteksi perubahan warna pada penelitian ini menggunakan alat uji dengan sistem yang bersifat non- invasif, non-destruktif, menggunakan sumber cahaya non-inonisasi, mempunyai ketelitian yang tinggi karena menggunakan laser dan sensor CCD garis yang sangat peka. Penggunaan sensor CCD berbasis sistem optik telah memenuhi kriteria difraksi Fraunhofer karena mempunyai nilai $\mathrm{F}<1$. Rancangan alat yang digunakan dalam penelitian ini merupakan langkah awal dari Laboratorium Optika dan Aplikasi Laser Departemen Fisika Fakultas Sains Teknologi Universitas Airlangga untuk membuat rancang bangun alat diagnosis alternatif lain yang diperlukan oleh dokter gigi atau peneliti sebagai pengguna alat tersebut.

Perubahan warna ditunjukkan dengan tinggi rendahnya intensitas yang ditransmisikan dari sumber sinar laser He-Ne ke sampel yang mampu ditangkap oleh sensor CCD, nampak pada nilai maksimal sumbu Y dari grafik Gaussian yang tampak pada layar monitor. Nilai intensitas tertinggi pada grafik Gaussian menunjukkan gelombang laser $\mathrm{He}-\mathrm{Ne}$ yang dapat ditransmisikan oleh sampel, oleh karena itu pengaturan alat yang tepat sangat penting dalam proses penelitian. Pengaturan alat dilakukan dengan menempatkan sampel diantara sensor CCD dan laser $\mathrm{He}-\mathrm{Ne}$ kemudian mengatur jarak antara sampel dengan sensor CCD dan sampel dengan laser He-Ne. Jarak antara objek dengan sensor CCD adalah 57 $\mathrm{cm}$, sedangkan jarak antara objek dengan sinar laser $\mathrm{He}-\mathrm{Ne}$ adalah $20 \mathrm{~cm}$. Jarak tersebut telah diuji sehingga laser $\mathrm{He}-\mathrm{Ne}$ mampu melewati sampel dan dapat ditangkap oleh sensor CCD kemudian hasil yang menunjukkan tingkat intensitas warna dari sampel ditampilkan dalam bentuk grafik Gaussian. ${ }^{8}$

Pada penelitian ini. nilai intensitas tertinggi pada kelompok kontrol sebesar 3722 lux sedangkan nilai intensitas terendah pada kelompok 
perlakuan III yang direndam dalam teh hitam selama 5 menit sebanyak 14x adalah 2845 lux. Penurunan nilai intensitas tersebut berhasil dideteksi oleh sensor CCD yang diikuti juga oleh perubahan nilai $d x$. Hal ini terlihat pada layar dari grafik Gaussian, perubahan nilai $d x$ didapat dari selisih nilai $\mathrm{X} 1$ dan $\mathrm{X} 2$ pada sumbu $\mathrm{X}$ grafik Gaussian pada gambar 1A dan 1B. Nilai X ini menunjukkan lebar celah yang berkaitan dengan posisi sampel. Nilai $d x$ yang panjang diperoleh puncak grafik Gaussian yang rendah, menunjukkan zat warna yang diserap oleh SIK banyak, terlihat dari warna sampel yang lebih gelap. Nilai $\mathrm{dx}$ yang pendek diperoleh puncak grafik Gaussian yang tinggi, menunjukkan zat warna yang diserap oleh SIK sedikit, terlihat dari warna sampel yang lebih terang. Warna sampel yang semakin gelap, menunjukkan intensitas yang rendah tampak dari puncak grafik Gaussian yang rendah karena sinar yang ditransmisikan kecil. Perubahan nilai intensitas yang ditunjukkan dengan tinggi atau rendah puncak grafik Gaussian yang terdeteksi pada sumbu $\mathrm{Y}$ dan nilai $d x$ menunjukkan tingkat sensitivitas yang tinggi dari sensor CCD sebagai alat ukur untuk mengetahui perubahan warna.

Perubahan warna pada SIK dapat disebabkan oleh beberapa faktor, antara lain ukuran dan mikroporositas sampel, dan lama kontak antar bahan. Semakin luas ukuran sampel maka kemungkinan kontak dengan larutan akan semakin besar sehingga perubahan fisik dapat terjadi.

Uji Anova satu arah menyatakan bahwa terdapat perbedaan intensitas warna yang bermakna pada semua kelompok perlakuan. Dari uji LSD didapatkan hasil perbedaan yang bermakna pada setiap kelompok sampel perlakuan. Hal ini disebabkan oleh faktor internal dan eksternal yang mempengaruhi SIK. Faktor internal dari SIK yang berpengaruh adalah saat proses pengerasan dari SIK. Pada proses pengerasan, ion sodium dan fluor tidak dapat berikatan satu sama lain secara sempurna, sehingga ada fluor yang terlepas menyebabkan struktur partikel SIK terjadi rongga kosong atau mikroporositas. $^{9} \quad$ Mikroporositas menentukan terjadinya penempelan partikel warna pada daerah porus, semakin banyak porusitas maka akumulasi dari zat warna yang terabsorbsi juga semakin banyak. Hal tersebut terlihat dari warna kelompok perlakuan SIK setelah direndam dalam larutan teh hitam selama 5 menit diulang 5 kali, 7 kali, dan 14 kali menjadi lebih gelap, jika dibandingkan dengan warna SIK yang direndam dalam larutan saline sebagai kelompok kontrol.

Faktor eksternal dari SIK yang mempengaruhi perubahan intensitas warna adalah karakter dari teh, yaitu flavonoid, tehflavins (TFs) dan teharubigins (TRs). Teh hitam merupakan minuman dengan zat warna alami yang memiliki komponen bioaktif yaitu flavonoid. Semen ionomer kaca yang berkontak dengan teh hitam memungkinkan terjadi interaksi antara komponen bioaktif dalam teh hitam tersebut dengan SIK. Flavonoid merupakan golongan polifenol. Polifenol dapat mengganggu ikatan partikel SIK dalam matrik asam poliakrilik, ${ }^{10}$ sehingga ikatan dalam matrik tersebut semakin renggang dan rongga kosong dalam SIK akan bertambah banyak. Selama ada kontak antara SIK dengan teh hitam, rongga kosong ini akan terisi oleh tehflavins (TFs) dan teharubigins (TRs) yang merupakan zat warna dalam teh hitam. Kondisi ini yang menyebabkan perubahan intensitas warna SIK setelah direndam dalam larutan teh hitam yang teridentifikasi dari layar yang ditunjukkan dengan puncak grafik Gaussian yang rendah.

\section{SIMPULAN}

Dari pembahasan penelitian ini disimpulkan 
semakin lama semen ionomer kaca diredam dalam larutan teh hitam semakin rendah intensitas perubahan warna yang terdeteksi, perubahan intensitas yang paling rendah direndam selama 5 menit diulang 14 kali.

\section{SARAN}

Karena penelitian ini merupakan kajian awal dan hanya menawarkan metode untuk mendeteksi perubahan warna pada bahan berdasarkan pola intensitas sehingga tidak dapat mengetahui efek dari lama perendaman secara mikroskopis, maka selanjutnya perlu pengkajian ke arah kajian mikroskopis sesuai dengan bidang ilmu yang terkait, misalnya fisika bahan, bahan kedokteran gigi, fisika komputasi dan instrumentasi.

\section{DAFTAR PUSTAKA}

1. Mc Cabe JF, Walls AWG. Applied dental material. $9^{\text {th }}$ Ed. Munksgaard: Blackwell; 2008. p. 245.

2. Anusavice KJ. Phillips' science of dental materials. $11^{\text {th }}$ Ed. Pennsylvania: W.B. Saunders Company. 2003. p. 471-8.

3. Ertas E, Guler AU, Yucel AC, Koprulu H, Guler E. Color stability of resin composites after immersion in different drinks. Dent Mater J 2006; 25 (2): 371-6.

4. Sibuea P. Minum teh dan khasiatnya bagi Kesehatan. 2009. [cited 2009 July 10].
Available from: http://www.alumniits.com/ index.php?...minum-teh-dan-khasiatnya-bagikesehatan...kesehatan.

5. Awliya W, Hassan K. In-vitro assessment of microhardness of composite resins as affected by immersion in different beverages. $\mathrm{J}$ Pakistan Dent Assoc 2005; 14 (4): 195-9.

6. Anita-Yuliati, Retna-Apsari, Yhoseph-Ghita, Suhariningsih. Kajian karakteristik perubahan intensitas warna resin composite menggunakan metode optik berbasis pola intensitas difraksi dari output sensor charged coupled device garis terkomputerasi. Prosiding Temu Ilmiah Nasional; 2009. Surabaya: 2009; 185-91.

7. Retna-Apsari, Yoseph-Ghita, Mardiningsih. Pemanfaatan difraksi fraunhofer dan sensor CCD garis untuk pendeteksian perubahan warna pada material gigi. Jurnal MIPA 2008; 11: 75-9.

8. Retna-Apsari, Yhoseph-Ghita. Analisis perubahan warna gigi berdasarkan distribusi intensitas pola difraksi dari output sensor CCD garis terkomputerisasi [tesis]. Surabaya: Universitas Airlangga; 2007. hlm. 21, 24-31.

9. Van Noort R. Introduction to dental material. $3^{\text {rd }}$ Ed. Philadelphia: Mosby Elsevier; 2007. p.135.

10. Mayangsari T. 2003. Perubahan intensitas warna compomer pada perendaman teh hitam dengan waktu yang berbeda [skripsi]. Surabaya: Fakultas Kedokteran Gigi Universitas Airlangga; 2003. hlm. 26-7. 